the corresponding seventeen weeks of the preceding year, the fatalities were reduced 52 per cent and the number of injured $11 \cdot 6$ per cent. In Glasgow it was found that the installation of light signals at certain junctions reduced the number of accidents by about 75 per cent.

\section{Farmer's Guide to Agricultural Research}

For the past ten years, the Royal Agricultural Society of England has issued annual summaries of research work carried out in the leading branches in agriculture. The publication, known as the "Farmer's Guide to Agricultural Research", is now issued as a section of the Society's Journal, so that it may be automatically in the hands of all members. A fow copies are published separately for private circulation, and a limited number of copies of previous issues (1925-33) are still available. The Society has now published its Journal for 1935 (vol. 96). The various sections of the Farmer's Guide are similar to those of the previous year, as are also the authors responsible for them. The remainder of the Journal consists of a number of special articles of outstanding interest, reports of the research work carried out under the ægis of the Society, together with a number of official reports. The volume may be obtained from the headquarters of the Society, 16 Bedford Square, London, W.C.1 (price 15s.).

\section{"Index Generalis"}

THE editor of the "Index Generalis", the 1936 issue of which was noticed in NATURE of July 18 (p. 100), asks us to state that new items for inclusion in this reference work are welcomed. They should be in the form in which they are to appear in print, and should be sent to Prof. R. de Montessus de Ballore, directeur de l'Index Generalis, Sorbonne, Paris $V^{e}$. No charge is made for insertions, and there is no obligation to purchase the volume. The only stipulations are that the information should be up to date and that it be revised annually on the request of the editor.

\section{Announcements}

Mr. R. Coppock, general secretary of the National Federation of Building Trades Operatives, $\mathrm{Mr}$. Richard K. Law, M.P., and Prof. B. A. McSwiney have been appointed members of the Industrial Health Research Board of the Medical Research Council.

Prof. A. Matae, professor of botany in the University of Lille, has been elected Correspondant of the Section of Botany of the Paris Academy of Sciences, in succession to the late Prof. H. Jumelle, professor of botany in the University of Marseilles.

The Trustees of the Busk studentship in aeronautics, founded in memory of Edward Teshmaker Busk, who lost his life in 1914 while flying an experimental aeroplane, have awarded the studentship for the year 1936-7 to Mr. J. W. E. Clarke, Glasgow.
Prof. Paut Uhumnuuth, director of the Institute of Hygiene at Freiburg i.B., has been nominated a foreign member of the Royal Academy of Sciences of Stockholm in recognition of his outstanding contributions to hygiene and bacteriology.

THE twenty-eighth annual Autumn Meeting of the Institute of Metals will be held in Paris on September 14-18. The fifteenth Autumn Lecture will be delivered. in the Grande Salle, Maison de la Chimie on September 14, at 8 p.m., by Prof. P. A. J. Chevenard, who will speak on "The Scientific Organization of Factories". Further information can be obtained from the Secretary, Institute of Metals, 36 Victoria Street, London, S.W.1.

A provisionax programme has been issued of a General Discussion of the Faraday Society to be held in the Chemistry Theatre, University of Edinburgh, on September 24-26 on "Structure and Molecular Forces in (a) Pure Liquids and (b) Solutions". The scope of the meeting does not extend to kinetics, which will form the subject of a forthcoming meeting, or to subjects which have been dealt with at recent meetings, such as dipole moments and the theory of strong electrolytes. A general introduction is promised by Prof. J. Kendall. The introductory paper in Section A (Pure Liquids) will be by Prof. F. London (Oxford), and that in Section B (Solutions) by Prof. J. H. Hildebrand (Berkeley, California). As is usual in these discussions, a number of foreign guests have been invited to take part. Particulars of the meeting can be obtained from the Secretary, Faraday Society, 13 South Square, Gray's Inn, London, W.C.1.

Applicatrons are invited for the following appoint. ments, on or before the dates mentioned :

An assistant for abstracting, indexing and proofreading in the Imperial Bureau of Animal Nutrition, Rowett Research Institute, Aberdeen-The Deputy Director (August 3).

An assistant lecturer and demonstrator in physics in the University of Leeds-The Registrar (August 10).

A lecturer in physiology (Grade II) in the Uni. versity of Bristol-The Registrar (August 12).

A general inspector of education and research, agricultural and horticultural division of the Ministry of Agriculture and Fisheries-The Secretary, Minister of Agriculture and Fisheries, 10 Whitehall Place, S.W.1 (August 12).

A professor of physics (August 31) and an assistant in bacteriology (August 20) in the University of Cape Town-The Secretary, Office of the High Commis. sioner for the Union of South Africa, Trafalgar Square, London, W.C.2.

Structural engineering assistants for the Designs Branch of the Directorate of Fortifications and Works-The Under-Secretary of State (C. 5), The War Office, London, S.W.1.

A physicist or applied mathematician to the British Cotton Industry Research Association-The Director, Shirley Institute, Didsbury, Manchester. 